\title{
The Writing on the Void: The Poetry of W. S. Merwin
}

\section{Harvey Gross}

The "three qualities which are seldom found together except in the greatest poets," Eliot notes, are "abundance, variety, and complete competence." Still in his early forties, Merwin has published an even dozen volumes: six of original verse and six of translations. Here we certainly find abundance. Merwin's talent is steady and opulent; he does not, like some of his contemporaries, squeeze out an undernourished volume every decade. He is not always equally good and there are only a few poems from his earlier books that I would care to anthologize. But when he is good, there is no one writing poetry today who approaches him. He possesses a narrow range of subjects and possibly an even narrower range of tone. Yet within his limitations-which are also strengths-we find a full representation of forms and feelings: all the lyrical genres and excursions, like "East of the Sun and West of the Moon," into the lush country of Keatsian narrative.

When a critic speaks of a poet's "complete competence," we think of technique and matters of metric and stanza, metaphor and trope, image and structure. No one knows what is the exact and deep relationship between technique and aesthetic effect; and in the most successful poetry technique becomes a transparency through which the meaning shines. We might wonder whether metric, as the rhythmic realization of feeling, or metaphor, perhaps the very ground of poetic existence, are even technical elements. A poet's rhythm articulates his ways of feeling; his metaphor projects his Weltanschauung. His voice, his rhythm, his vision: the particular ways of relating the disparate parts of existence, are also his meaning. I am not describing the ontological status of all poems, of poetry as such (whatever that may be) but formulating a theory of value. In the best poems voice and vision are not merely facts for critical and technical analysis; the how and the what coalesce into what simply is.

I thus am hard put to separate Merwin's 'method' from his subjects in his latest and most amazing performance, The Lice. The lines move to no metric we can count and parse. We may name his tropes; but if we point out, in his poem "Wish," that uniforms are containers for things contained and Necessity is allegoria, we are merely bright boys understanding poetry: 


\section{WISH}

The star in my

Hand is falling

All the uniforms know what's no use

May I bow to Necessity not

To her hirelings

We can see how Merwin came to write so well. His first volume, A Mask for Janus, exhibits a young musician trying out his instrument. He composes sestinas, ballads, carols, songs, and roundels: the formal verse of the early fifties. Merwin follows the prevailing fashion (it was a good fashion for poets to train in: so different from the aggressive, politically dominated espousal of sincerity and ignorance which characterizes the present mood). In this first book Merwin understands the myriad possibilities inherent in traditional English metric. $\mathrm{He}$ handles well the freedom allowed by iambic verse; he exploits all the variations possible within the restraint of the metrical code:

Hills are to be forgotten; the patter of speech

Must lilt upon flatness. The beasts will come;

And as they come, let one man, by the ark,

Drunken with desolation, his tongue

Rounding the full statement of the seasons,

Tremble and stare, his eyes seeming to chase

A final clatter of doomed crows, to seek

An affirmation, a mercy, an island,

Or hills crested with towns, and to find only

Cities of cloud already crumbling.

\section{"Dictum: for a Masque of Deluge"}

"Drunken with desolation, his tongue/Rounding the full statement of the seasons ..." has a Tennysonian rotundity of vowel music, a perhaps dangerous fluency and a too obvious fitting of sound to sense. But Merwin's ear for English quantity is no matter of pretty sounds or onomatopoeic effects. What he learned (and what obviously became second nature to him) about metrical quantity is transformed into piercing quality in "The Asians Dying" (from The Lice) :

Rain falls into the open eyes of the dead

Again again with its pointless sound

When the moon finds them they are the color of everything

Merwin learns his craft in A Mask for Janus. In his second volume, The Dancing Bears, he searches out a number of themes. One is clearly signaled in a title, "On the Subject of Poetry." The voice of the poem laments, 
I do not understand the world, father.

By the millpond at the end of the garden

There is a man who slouches listening

To the wheel revolving in the stream, only

There is no wheel there to revolve.

He sits in the end of March, but he sits also

In the end of the garden; his hands are in

His pockets. It is not expectation

On which he is intent, nor yesterday

To which he listens. It is the wheel turning.

Merwin's themes here are familiar post-symbolist concerns: the identity of poem and world; reality as imaginative construct; aesthetic experience as not separable from other kinds of human experience. The poet is neither a prophet, a foreteller of the event: "It is not expectation/On which he is intent . . ." nor is he a historian: “. . . nor yesterday/To which he listens. . . ." He simply hears the turning wheel, the turning world which he magically invents through the creative expedient of listening. Thus the process appears circular and incomprehensible to the ordinary logic of the poem's simple-minded persona:

I do not think I am fond, father,

Of the way in which always before he listens

He prepares himself by listening. . . .

Merwin's turning wheel recalls Stevens' “. . . essential poem at the center of things":

It is

As if the central poem became the world,

And the world the central poem, each one the mate

Of the other, as if summer was a spouse,

Espoused each morning. ...

“A Primitive Like an Orb”

The concern with magic and myth as creative expedients is intensified in the long poem which forms the center of The Dancing Bears, "East of the Sun and West of the Moon." Merwin takes his title, much of his atmosphere, and some of his actual language from the Norse fairy tale collected by Peter Asbjørnsen and retold in English by Sir George W. Dasent. "East of the Sun and West of the Moon" is a Norse version, with embellishments such as Trolls and large White Bears, of Apuleius' tale of Cupid and Psyche. The story tells of a Beauty espoused by a Beastly Husband who keeps both his identity and human appearance secret from his bride. Her mother naturally finds fault with such an unconventional arrangement and questions the whole matter despite the fact that the Prince is bona fide royalty (transmogrified by a Wicked Witch) who maintains Beauty in appropriately sumptuous and magical surroundings. Mother urges daughter to disobey the Husband's thou-shalt-not-peek commandment: 
'Take better than advice, this end of candle

To light when he sleeps next you in the dark;

Only be careful that no drops fall.

The daughter lights the candle and gazes on the forbidden features of her mysterious husband; taken with his beauty, she leans over and kisses his head:

Three times

The tallow folly from the candle fell ....

(In Cupid and Psyche oil from Psyche's lamp spurts on the sleeping god's right shoulder.) The prince awakes and scolds the girl for her impatient curiosity:

'Why could you not entertain

A curious patience but for one whole year,

For then had we been saved, and my spell broken.

Now this kingdom must shatter and I depart

For the wheeling castle of my stepmother

And marry a princess with a nose three ells long

When I might have married you.'

She wakes the next morning and finds kingdom, castle, and her charmed lover gone. Now she must begin the long quest to find the palace, "farther than dreams, that lies/East of the sun and west of the moon ...."

As she wends her dismal disenchanted way, through "a landscape of exceptions," a sententiously moralizing bird (derived perhaps from Eliot's Burnt Norton) sings out Merwin's theme:

Skeptical bird she settled in a tree

And sang, 'All magic is but metaphor.'

Metaphor and myth function to make "a familiar mystery" out of nature and human suffering and struggle; poetry, the embodiment in language of a particularizing magic, makes the world humanly tolerable and in doing so creates the veritable world. Merwin's theme, like a phrase in music, is inverted in the poem's penultimate stanza:

'All metaphor,' she said, 'is magic.' Let

Me be diverted in a turning lantern,

Let me in that variety be real.

And in the poem's concluding lines we hear, in a full restatement, the moral of "East of the Sun and West of the Moon":

Now, even now, over the rock hill

The tropical, the lucid moon, turning

Her mortal guises in the eye of a man,

Creates the image in which the world is. 
Our moon assumes the twin masks of magic and metaphor-masks which make her known both to herself and to men. What she knows is myth, the fairy story and its imagined creatures and enchanted objects:

'Oh, who would be shown, save in analogy,

-What for gold handsels and marvelous equerry-

As three hags sitting under an apple tree?'

Save in analogy, in myth and the usages of figurative language, human knowledge is not possible; what is humanized is mythologized and made poetry. Commenting on Merwin's adaptation of a Norse fairy tale which is, in turn, an adaptation of a Latin fairy tale, the lady-in-the-moon notes that any telling of the myth must be illuminated by the light of imagination, that the lamp or candle streaming in darkness must always discover a different prince:

'But let the story be an improvisation

Continually, and through all repetition

Differ a little from itself, as though

Mistaken; and I a lady with foreign ways

To sing therein to my own hair.'

"East of the Sun and West of the Moon" is characterized by brilliance and richness of style and by passages which might have originated in The Eve of St. Agnes or Lamia:

Their eyes
Enormous with the dark, a hall they entered
That blazed between mirrors, between pilasters
Of yellow chrysolite; on walls of brass
Gold branches of dead genealogies
Clutched candles and wild torches whence the flames
Rose still as brilliants. Under a fiery
Garnet tree with leaves of glass, sunken
In a pool of sea-green beryl as in still water
A golden salmon hung. And no sound came.

Congruent with the poem's thematic obsession, metaphors of obliqueness and affective resonance ornament the texture of every stanza. We note elaborate similes that are touched with mockery,

The moon was thin as a poor man's daughter

At the end of autumn ...

metaphors that ascribe to things human process,

The wall healed behind them ...

tropes of humorous extravagance that recall Stevens (who is the controlling warlock directing the magic of "East of the Sun and West of the Moon") : 
She was greeted like a lost season.

Daylong she walked again in affluent summer ....

"East of the Sun and West of the Moon" seems only a qualified success. As a philosophical poem about the nature of poetry and the relation of imagination to reality, it invites comparison with Stevens' explorations of the fictive realm and the "formulations of midnight." Perhaps Merwin sensed that although the poem maintained a consistently lovely aural and visual surface, it did not sustain either a high level of narrative interest or the vjgorous logic of intellectual argument: it remains the isolated example of an extended poem in Merwin's body of work.

The first dozen poems of The Drunk in the Furnace (1960) are seascapes, sailor's yarns, and poems of fabled voyages. They take their tone and technique (it appears to me) from Eliot's "The Dry Salvages" and are written in loosened blank verse metric which moves the lines along an irregular but subtly controlled rhythm. Mythic journeys have always intrigued Merwin (the two opening poems of his first book are "Anabasis I" and "Anabasis II"); they are the metaphoric motive power urging many of his poems. In his recent work the mythic journey may be compressed into a single, startling image; here is "The Defeated" (from The Moving Target) :

Beyond surprise, my ribs start up from the ground.

After I had sunk, the waters went down.

The horizon I was making for runs through my eyes.

It has woven its simple nest among my bones.

The protagonist has gone down in the desert, pierced through by the distant horizon which is also, magically, a bird. In "The Frozen Sea" (from The Drunk in the Furnace), the protagonists (polar explorers) walk a white and solid ocean "To the pure south, [where] whichever way we turned/Was north. . . ."

I read "The Frozen Sea" as a nearly classic parable of the American moral experience: Captain Ahab's furious impulse to avenge injury and confront the inscrutable whiteness of the whale. Thus the overwhelming desire to extirpate evil from the world, the radical innocence of Billy Budd, the Calvinist insistence on unmixed moral absolutes-all turn against the very principles they assert and become agents of evil. American goodness is intolerable, American purity hypocritical:
... it was not any light
From heaven that hurt our eyes, but
The whiteness that we could not bear. It
Turned bloody in our carnal eyes. Virtues
That had borne us thus far turned on us, peopling
The lashed plains of our minds with hollow voices
Out of the snouted masks of beasts. Their
Guts would feed on God, they said.

The explorers continue their journey toward the absolute south sustained by the 
fierce pride of their inflexible convictions. They look neither to the right nor left; the whiteness bears them up. The whiteness of the whale, the whiteness of Billy softly gleaming in the darkness of the brig, the sickening whiteness of Hilda in The Marble Faun. The end of the journey through whiteness brings them to tragic insights, that

\section{... how small we were around whom the howling World turned ...}

that they had not plucked out the frozen heart of the mystery of the world, but on reaching the still point of absolute south, they had nowhere to go.

Two poems in The Drunk in the Furnace, "No One" and "One-Eye" play intriguing music on the theme of apocalypse. "No One" speculates on the Last Judgment which shall overtake those who have conspired in the death of God. On that final day

... when the wind of prophecy

Lifts its pitch, and over the drifting ash

At last the trump splits the sky,

No One should arise.

"One-Eye" awakes to consciousness in the country of the blind,

$$
\text { ... come to them }
$$

Out of a saying. And chanting an anthem

Unto his one eye, to the dry

Accompaniment that their leaping fingers made

Flicking round him like locusts in a cloud,

They took him home with them.

He lives, of course, as king in the realm of the unsighted. Around him the blind listen, "Amazed at his royalty, gaping like/Sockets. . . ." They learn from him the wonders of the visible world but he keeps them in blissful ignorance of impending catastrophe, the End Which is Coming:

$$
\begin{aligned}
& \text {... the black thumb as big as a valley } \\
& \text { Over their heads descending silently } \\
& \text { Out of a quiet sky. }
\end{aligned}
$$

One possible way to describe the two books which succeed The Drunk in the Furnace, The Moving Target, and The Lice, is that they are written after the end; the poems they contain are fragmentary messages scratched on shards and crumbling stones. The Moving Target (1963) breaks with the formal tradition of the fifties and marks a major stylistic advance for Merwin. This new style is terse, epigrammatic, and above all, powerfully concentrated. Merwin's earlier tendencies toward elegant and prolix elaboration (the "Cansos" in The Dancing Bears) are curbed. The formal stanzas and fluid meters are replaced by a new, frequently line-stopped rhythm and use of blank space to mark breathing pauses:

Today is in another street 
I'm coming to that

Before me

The bird of the end with its

Colorless feet

Has walked on windows

("The Crossroads of the World, etc.")

Themes and concerns appear and re-appear in epigram; indeed Merwin's new style has re-vitalized the epigram and given it new expressive capabilities. Some of the poems in both The Moving Target and The Lice are only three lines in length; in The Moving Target we find what surely must be the most powerful one-line poem in English, an epitaph for the alienated of every extremity:

\section{SAVONAROLA}

Unable to endure my world and calling the failure God, I will destroy yours.

The startling poetic accomplishment of The Moving Target, its permanent imaginative achievement, inheres in Merwin's ability to breathe life into the dry bones of metaphor. Earlier I noted that metaphor is Weltanschauung, the projection of a world. The surrounding world of The Moving Target (and The Lice) is still and intense, its metaphors generating the familiarly strange (and strangely familiar) ambience of the dream. 'Surrealistic' is our first response to this poem:

\section{DEAD HAND}

Temptations still nest in it like basilisks.

Hang it up till the rings fall.

As we move through the metaphoric landscape of The Moving Target, we note that what initially seemed programmatically surrealistic (derived from such poets as Neruda or St.-J. Perse) develops a personal, numinous quality. Sometimes Merwin, in the manner of such humorists as S. J. Perelman, drags a 'dead' metaphor (a comparison bludgeoned into cliché) startled and kicking from the grave:

And the hands of the clock still knock without entering.

Or, even more characteristically, he crosses the wires of perception in synaesthesis. So frequently does Merwin employ figures like these,

Your absence has gone through me

Like thread through a needle,

Everything I do is stitched with its color. . . .

that synaesthesis becomes a persistent mannerism, a tick in the physiognomy of Merwin's style. At times Merwin just fools around with surprising juxtapositions, creating gratuitously daft effects; at other times the juxtapositions fall into place 
and we have, in this example, something akin to frozen hysteria:

Be here the flies from the house of the mapmaker

Walk on our letters I can tell

And the days hang medals between us

I have lit our room with a glove of yours be

Here I turn

To your name and the hour remembers

Its one word

Now

In these lines rhythm, controlled by syntax and not by meter, is as startling as the effects of metaphor. The caesuras are moments of silence between the larger clauses of meaning:

Be here ... the flies from the house of the mapmaker

Walk on our letters . . . I can tell ...

Merwin uses silence, time's emptiness, as Beethoven (in his later music) uses the held rest to build up expressive tension. Such usage, of course, characterizes a poetry meant primarily for performance where the reader can stop, accelerate, vary dynamics, and so on. But Merwin makes it absolutely clear, even to the silent reader, how he expects his rhythm to sound; a voice, querulous, hesitating, slightly impatient, sometimes annoyed, speaks from the cold black and white of the printed page:

\section{INVOCATION}

The day hanging by its feet with a hole

In its voice

And the light running into the sand

Here I am once again with my dry mouth

At the fountain of thistles

Preparing to sing.

The slightly disingenuous complaint here is familiar and traditional: a master of language and rhythm tells us, in poetry which belies his assertion, that he is neither ready nor competent to perform his office. Like the soprano who tells us she is not in voice or the pianist who says he has not practiced all week, he protests that his talents are unequal to his task. Words are of limited value; there is an unreachable perfection in silence. But paradoxically the poet must speak of silence; to paraphrase Sweeney, he's gotta use words when he talks to us.

The last poem in The Moving Target makes a number of implied assertions about the possibilities and impossibilities of a poetry of silence: 


\section{DAYBREAK}

Again this procession of the speechless

Bringing me their words

The future woke me with its silence

I join the procession

An open doorway

Speaks for me

Again

This poetry strives to move beyond language, to confront directly the phenomenon language reaches toward. There is, of course, no poetry beyond language; it is in metaphor that the poet reaches his vision. "Daybreak" is an example of total synaesthesis; the entire poem tells us of a speechless procession of light, of the new day (the future) with its wordless and undeniable invitation, and of an open space (doorway) which breaks into speech. All this does not make a poetry of silence but a poetic language alive with a plenitude of meaning. The silence of "Daybreak" itself is metaphor; the soundless nature of light and the dumb future enforce what Philip Wheelwright calls ". . . epiphoric vitality, since the compression of one type of sense-impression [in synaesthesis] with that given by a different sense-organ stirs the reader to reflective contemplation along two of his avenues of sense at once."

The Moving Target generally avoids poems in a direct representational mode. Person, place, or thing confront us in metaphoric transformations; gestures are deformed, grotesque, or sinister and threatening:

"Or this character gets on a bus with an open razor. . .." All the poems delineate the eerie quality of behavior and feeling in a post-apocalyptic world: after the end but before another beginning. We catch occasional glimpses (as in a dream or in the seemingly preternatural experience of déjà-vu) of recognizable places. The poem "The Crossroads of the World etc." is about New York City; Merwin offers certain specifics of place and time:

I would never have thought I would be born here

So late in the stone so long before morning

Between the rivers learning of salt

But the city soon becomes an image for any city afflicted by time and ruin, a type for the void at the end of history when

The bird of the end with its

Colorless feet

Has walked on windows ... .

The Lice (1967) continues the mode and mood of The Moving Target, but the thematic direction is more clearly articulated; Merwin finds his way to a

* Metaphor and Reality (Indiana University Press, 1962) p. 76. 
variety of subjects suitable to his style. Or we might say he develops numerous aspects-political, polemical, even (in the poem "The Last One") ecological-of the post-apocalyptic theme. A number of poems express the quality of moral life in the last decade-not in specific political protests but in sombre evocations of feeling. All of the poems stay very close to the center of Merwin's concern; consequently, The Lice is a very tightly written book: a set of sermons on a single text. Because of its thematic and expressive concentration, The Lice has a cumulative impact unlike most collections of verse; it is Merwin's most important work: an astonishing achievement already widely imitated.

The world at the end of history is a dead world. All the poet can do is to read ... what the five poplars are writing On the void. ...

$$
\text { (“A Scale in May") }
$$

Perhaps the most frequently repeated words in The Lice are dead, death, and silence; their repetition echoes in Merwin's twilit void. "The Hydra" begins with this assertion:

No no the dead have no brothers

The Hydra calls me but I am used to it It calls me Everybody

But I know my name and do not answer

I am not sure who the Hydra is in this poem, but his mythic implications seem clear. He is the many-headed Beast of the Apocalypse and Hercules' self-renewing and nearly unkillable antagonist; he is the recurring Creature of the End. The poet is used to his call; those who have gazed long into the abyss (as Nietzsche notes) get accustomed to having the abyss gaze into them. The slangy familiarity ("but I am used to it") domesticates the Beast; even the Apocalypse becomes bearable if regarded through ironic detachment. Or perhaps the poet is saying so what? to the apocalypse-as Augustine remarks, "It is no news to see a monster under the sun."

Such irony relieves the pessimism of The Lice. "Some Last Questions," a riddle poem in the gnomic Anglo-Saxon tradition, gives wild and whirling answers to some basic questions:

What is the head

What are the eyes

$$
\text { A. Ash }
$$

A. The wells have fallen in and have Inhabitants ...

By this time we are used to Merwin's brilliance in metaphor as we are accustomed to his obsession with speech and silence, and with the difficulty of finding words to penetrate the void: 
What is the tongue
A. The black coat that fell off the wall
With sleeves trying to say something

"Some Last Questions" brings us to the brink of death but makes some necessary qualifications: the silence must be broken with words; it is not a sufficient condition even in the city at the end of time:

\section{What is the silence}

\section{A. As though it had a right to more}

Death must be mitigated through the memory of those who remain; the substance of the dead is translated, like the heroes of mythology, to the heavens:

Who are the compatriots

\section{A. They make the stars of bone}

My interpretations of "The Hydra" and "Some Last Questions" do not claim to be more than sight-readings, attempts at gaining some general outlines of the music. Merwin's recent poetry resists paraphrase or categorization. Earlier I quoted "Wish"; we note that uniforms may be metonymy for the military, that Necessity may be allegoria for some higher process. When the poet wishes to "bow to Necessity not/To her hirelings ...", he says he would gladly yield his substance to the seasons, to the cosmos, to nature but not to human hate and aggression. This is a possible reading of the poem's propositional sense. But I would hesitate to call "Wish" an anti-war poem. It is a poem 'about' moral emotion in the same way that Beethoven's Fifth Symphony is 'about' man's struggle with the force of destiny.

Two of the most impressive performances in The Lice, "The Last One" and "The Asians Dying," are protests against human atrocities. "The Last One" dramatizes nature's revenge against men who

$$
\begin{aligned}
& \text {... made up their minds to be everywhere because } \\
& \text { why not } \\
& \text { Everywhere was theirs because they thought so. }
\end{aligned}
$$

“The Asians Dying” is 'about' the war in Viet Nam; it is also about Napoleon's Russian campaign, the Punic Wars, the Peloponnesian War. Merwin carefully avoids both the stylized rhetoric of protest and the moralizing piety of selfrighteous indignation; and because the voice of The Lice never raises itself above a whisper, "The Asians Dying" is a dark prophecy, classically understated. The final strophe, mezzo piano, tells us what we have all painfully learned and imagines the holocaust we hope may never come:

The possessors move everywhere under Death their star Like columns of smoke they advance into the shadows Like thin flames with no light They with no past

And fire their only future 
It may be presumptuous of me to say this but I hope Merwin does not stay locked into the stylistic mode of The Lice. I catch, in some of his recently published verse, notes of self-imitation. These dissonances are inevitable in the work of any highly prolific writer who develops an intensely original verbal quality; and we have perhaps learned to expect the incredible virtuosity of a figure like this:

And I look up but it is only

Evening again the old hat without a head

The danger is that we may not see the poetry for the thickness of the metaphor. There is a sense of strain, of trying to infuse vitality into a language nearly dead of exhaustion. The Lice is, of course, a book of elegies (Merwin has been from the beginning, an elegiac poet); but sometimes Merwin's elegiac voice sounds like a voice from the grave. He means it to be; it is tinged with irony and modulated with comic self-deprecation. In a poem from his first volume, "For a Dissolving Music," the poet asks, "What shall be sung?" and this answer is given:

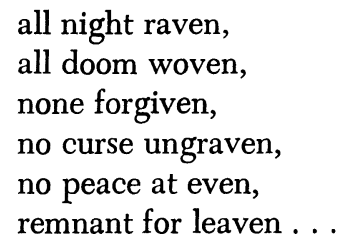

These notes have been necessarily brief and selective. I have not considered Merwin's work as a translator and the relationship between his original verse and the adaptations he has made from languages ranging through Spanish and French to Viet Namese and Peruvian. It is obviously a delicate and subtle relationship, not a crude matter of stylistic 'influence' or direct inspiration. Merwin remarks, "And I have not come to use translations as a way of touching off writing that then became deliberately, specially, or ostentatiously my own. On the contrary, I have felt impelled to keep translation and my own writing more and more sharply separate." While agreeing that Merwin is every inch his own man clothed in his own style and speaking in his own voice, I wonder if he has not caught some inflection of emphasis from lines like these:

Just the same it would be delicious

to scare a notary with a cut lily

or knock a nun stone dead with one blow of an ear.

It would be beautiful

to go through the streets with a green knife

shouting until I died of cold.

(These lines are from Pablo Neruda in Merwin's own translation.) Perhaps we can say (as Merwin reports Pound saying to him) that Neruda's work proved “. . . a means of . . . sharpening [his] awareness of the possibilities of his own 
language." Translation offers the poet neither an easy access to originality nor a source of exotic subject matter but rather a fresh appraisal of his own language and its resources of symbol, sound, and rhythm.

Merwin's work in translation reveals him "a good European" immersed in traditional culture. Similarly, his own poetry has little sense of the American region. The scene of his lyrics is the Imperial City frozen into its moment of terror and decay, where

The thug on duty says What would you change

He looks at his watch he lifts

Emptiness out of the vases

And holds it up to examine

Or the scene is nature suffused in a private sensibility, where the poet discovers not only moon, star, and tree but his own roots tangled in the sentient landscapes. Like Kafka the scene of Merwin's recent writing is in the City at the End of Things, in that ubiquitous Country of Nowhere; thus I have been tempted to read Merwin's poems as allegories with point for point meanings or parables with political or social morals. Because Merwin does not particularize, we feel the need to supply the full context. Again, like Kafka Merwin is a symbolist in a world emptied of God: where symbols are no longer believed but merely interpreted. And the spiritual agony occasioned by estrangement and the sense of loss informs the prophetic voice which does not trumpet but quietly sings, sotto voce, of The End.

After the apocalypse, the new dispensation; after the destruction of the spoilers and unbelievers, the rewarding of the saving remnant. Merwin, as far as I can tell from The Lice, believes both in the eternal circularity of history and some possible movement toward a new world. Men will do evil again (being men); they will repeat their folly and again hold contemptible values. When the war is over, Merwin comments, “. . . we will all enlist again." The peasant, in His Prayer To The Powers Of This World, after eloquently indicting the arrogance and cruelty of the oppressors, concludes

I am bringing up my children to be you ...

After the revolution, the oppressed become the oppressors and the cycle of arrogance and cruelty goes on. I am reluctant to accuse Merwin of positive thinking but the very fact that he assumes the prophetic office indicates some hope that his words will be heard. The movement toward the new world may be only the dry stirring of rats running in their cages. "Unfinished Book of Kings" reports the excited anticipation before the coming of a new dynasty; when it comes, it turns out to be "the last of the absences": Tweedledum or Tweedledee, Lyndon Johnson or Richard Nixon. "The lips of the extinct prophets still lay on the ground here and there murmuring So much for the hair of the moon ..."

But the lips do go on murmuring the magic of their metaphors. Apocalypse and End are also metaphors or as Frank Kermode (taking his cue from Wallace Stevens) notes, actually sustaining imaginative fictions. The poet finds it useful 
to think he is living at the end of an era; he has, at the very least, the security of his dissolution. I would also suggest that for Merwin and the line of poets he follows (Eliot, Yeats, Pound, St.-John Perse) The End has already taken place; their prophecies tell us nothing we have not known for a long time. Merwin's particular contribution has been a language and rhythm cleansed of all raw specificity which render how it feels to live in the polity of the credibility gap, among those who make revolution for the hell of it, and under those who make war to guarantee their own destruction. Perhaps such poetry can offer a measure of protection even though words are thin armor against the enemy, even though the poet makes his ritual disclaimer:

And that my words are the garment of what I shall never be Like the tucked sleeve of a one-armed boy

\section{The Night of the Shirts}

Oh pile of white shirts who is coming to breathe in your shapes to carry your numbers

to appear

what hearts

are moving toward their garments here

their days

what troubles beating between arms

you look upward through

each other saying nothing has happened

and it has gone away and is sleeping

having told the same story

and we exist from within

eyes of the gods

you lie on your backs

and the wounds are not made

the blood has not heard

the boat has not turned to stone

and the dark wires to the bulb

are full of the voice of the unborn 